\title{
The Influence Of Ownership And Type Of University On Work Environment In South West Nigerian Universities
}

B. B. Arogundade, University of Ado-Ekiti, Nigeria

\begin{abstract}
This paper examined the influence of ownership and type of university on work environment in South West Nigerian universities. The study population consists of all academic staff of the ten public and nine private universities in South West Nigeria. In all, 500 respondents selected from eight universities constituted the sample of the study. The respondents were selected using multi stage, stratified, purposive and simple random sampling techniques. The instrument tagged Work Environment Questionnaire (WEQ) was used to elicit relevant information from the respondents. The data collected were analyzed using frequency count, percentage and t-test statistics. The study revealed that the work environment of federal universities was favourable than that of state universities in terms of provision of physical facilities, information services, motivation, authority-staff relationship, participation in decision-making and staff development. The result showed that there was significant difference in the work environment of federal and state universities in favour of federal universities. The results also revealed that work environment in public and private universities was favourable but that of private universities was better than that of public universities. It also showed that there was no significant difference in the work environment of private and public universities. Based on the findings, it was recommended that owners of the universities should provide a favourable environment.
\end{abstract}

Keywords: Ownership; Work Environment; Academic Staff; University

\section{INTRODUCTION}

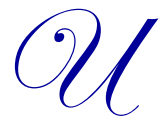

niversity education in developing countries, in particular, and in the world, in general, is seen as the only way the needed high level manpower for any country's development could be achieved. It was this expressed need to train more high level skill manpower that led to the establishment of the University College Ibadan (now the University of Ibadan) in 1948 and to the setting up of a high powered man commission, Ashby Commission in 1959 (Akangbou, 1985). The Commission recommended the establishment of more universities in the country so as to meet the manpower needs of the country during the first post-independence decade (1960-70). The creation of four new universities in 1962 was the outcome of the commission's report. Since then, more universities owned by the government and private individuals have been established.

It has been observed that work environment in federal universities is more conducive than in state universities in terms of physical facilities, leadership styles, motivational level of staff, and information network between the subordinates, perhaps that has been the factor responsible for environmental inequality in Nigerian universities. According to Adeyemi (2000), environment figures grow by the day. The facilities on ground in the state universities cannot cope with the upsurge in population of students seeking admission into the universities.

It has been expressed by education stakeholders that work environment in private universities is more conducive than that of public universities in terms of physical facilities, staff motivation, students' levels of discipline, effective information services, and stability in academic calendar. Private universities in Nigeria seem to 
experience greater stability than their public counterparts. Perhaps that is why the private universities have been able to run the normal university calendar.

These, therefore, raise the question about how to determine the influence of ownership and type of university on work environment of South West Nigerian universities.

\section{PURPOSE OF THE STUDY}

The purpose of the study was to determine if the work environment in the federal and state universities is favourable. The study also learned whether the work environment in the public and private universities is favourable and it also investigated the difference in the work environment of federal and state universities as well as the difference in the work environment of private and public universities.

\section{RESEARCH QUESTIONS}

1. Is the work environment in federal and state universities favourable?

2. Is the work environment in public and private universities favourable?

\section{RESEARCH HYPOTHESES}

HQ: There is no significant difference in the work environment of federal and state universities.

HQ: There is no significant difference in the work environment of private and public universities.

\section{REVIEW OF RELATED LITERATURE}

In Nigeria, studies have been conducted on the influence of ownership and type of universities as related to work environment. For example, Adesina (1983), Ajani (1988) and Adeyemi (2000), in their findings, asserted that academic staff from universities with better teaching facilities performed better than those with inadequate facilities. They added that academic staff scrambles for federal universities in preference to state universities because of the belief that most of the federal universities have a conducive environment and they also catered to the staff than those in the state universities who are serving under poor working conditions and environment.

The provision of good working environments by owners of the universities could motivate academic staff to work beyond a predetermined level if given attention. As a corrective measure, Ogunsanya (2000) cautioned that the academic staffs have to be adequately given the opportunity to work in a good environment by the owners of the universities if the universities education objectives are to be achieved. According to Hartnett (2006), it was noted that when government funding became insufficient to maintain institutional environment, universities elsewhere in the world sought to supplement their public funding with locally generated income."This is also true in Nigeria.

Another work environment problem identified by Alani (2000) is that Nigeria tertiary education, both federal and state, are short of equipment and learning materials. Essential textbooks are very scarce. He pointed out that the Nigerian Educational Research and Development Council (NERDC) has not achieved much in its book development policy as set out in the enabling decree.

In his own view, Bruns (2003) ascertained that work environment is concerned with attaining educational goals and objectives. In support of this, Arogundade (2009) explained that for any tertiary institution to live up to the expectation of producing high skilled labour and research output to meet the perceived economic needs, building new institutions of civil society, economy and facilitating new cultural values and training and socializing members of new social elites, the work environment must be viewed with special interest.

The work environment of private and public universities, as viewed by Lubienski (2005), suggested that public universities with conducive work environments were better than private universities with poor work 
environments. Some researchers reported that private universities with conducive work environments outperform public universities (Winkler \& Rounds, 1996; Tomer, 1996; Scheerens and Bosker, 1997; Seatle, 2005).

In view of the above findings, the study will sort out the influence of ownership and types of universities on work environments in South West Nigerian universities."

\section{METHODOLOGY}

This study is a descriptive research of the survey type. The population of the study consists of all academic staff of the ten public and nine private universities in South West Nigeria. The sample for this study was 500 academic staff selected from eight universities. Multi-stage, stratified, purposive and simple random techniques were used to select the sample. In the first stage, the universities were stratified according to type (private and public). Eight universities (four public, two federal-owned and state-owned universities) were purposive samples to take care of the variable of ownership. At the third stage, a proportional stratified random sampling technique was used to select the lecturers.

The questionnaire constructed for the study was Work Environment Questionnaire (WEQ) for academic staff. The respondents were asked to indicate their agreement or disagreement on the items in the questionnaire. The questionnaire was corrected by experts in educational management and experts in test and measurement. The questionnaire was also pilot-tested using 30 academic staff. The instrument was administered twice within an interval of two weeks. The two sets of responses were correlated using Pearson product moment correlation. Reliability co-efficient 0.88 was obtained for the WEQ. The data collected were analyzed using frequency count, simple percentage and t-test statistics. The hypotheses formulated were tested at 0.05 level of significance. Out of 500 copies of the instrument WEQ administered, a total of 484 copies were properly filled and retuned, and all were found usable for data analysis.

\section{RESULTS}

Question 1: Is the work environment in the federal and state universities favourable?

In answering the questions, the responses to items in WEQ were used.

Table 1: Suitability of Work Environment of Academic Staff in the Federal and State Universities

\begin{tabular}{|c|l|c|c|c|c|c|c|c|c|}
\hline \multirow{2}{*}{ S/N Items } & & \multicolumn{3}{c|}{ Public Universities } & \multicolumn{4}{c|}{ Private Universities } \\
\cline { 3 - 9 } & & Favourable & \multicolumn{2}{c|}{ Unfavourable } & \multicolumn{3}{c|}{ Favourable } & \multicolumn{2}{c|}{ Unfavourable } \\
\hline & & $\mathrm{F}$ & $\%$ & $\mathrm{~F}$ & $\%$ & $\mathrm{~F}$ & $\%$ & $\mathrm{~F}$ & $\%$ \\
\hline 1. & Physical facilities & 206 & 85.8 & 34 & 14.2 & 10 & 5.0 & 190 & 95.0 \\
\hline 2. & Information services & 207 & 86.2 & 33 & 13.8 & 30 & 15.0 & 170 & 85.0 \\
\hline 3. & Motivation & 200 & 83.3 & 40 & 16.7 & 41 & 20.5 & 159 & 79.5 \\
\hline 4. & Authority-staff relationship & 195 & 81.2 & 45 & 18.8 & 60 & 30.0 & 140 & 70.0 \\
\hline 5. & Participation in decision making & 193 & 80.4 & 47 & 19.6 & 54 & 27.0 & 146 & 73.0 \\
\hline 6. & Staff development & 212 & 88.3 & 28 & 11.7 & 56 & 28.0 & 144 & 72.0 \\
\hline & Mean & $\mathbf{2 0 2}$ & $\mathbf{8 4 . 2}$ & $\mathbf{3 8}$ & $\mathbf{1 5 . 8}$ & $\mathbf{4 2}$ & $\mathbf{2 1 . 1}$ & $\mathbf{1 5 8}$ & $\mathbf{7 8 . 9}$ \\
\hline
\end{tabular}

Table 1 compares the work environment of academic staff in federal and state universities. As shown in the table, an average of $84.2 \%$ of the respondents indicated that the work environment in the federal universities was favourable as against an average of $21.1 \%$ who indicated that the work environment in the state universities was favourable. This means that the work environment in federal universities was better than that of state universities. The table also shows that the work environment in the state universities was highly unfavourable.

Question 2: Is the work environment in the public and private universities favourable?

In order to answer this question, the responses to items in WEQ were used. 
Table 2: Suitability of Work Environment of Academic Staff in the Public and Private Universities

\begin{tabular}{|c|c|c|c|c|c|c|c|c|c|}
\hline \multirow[t]{3}{*}{$\mathbf{S} / \mathbf{N}$} & \multirow[t]{3}{*}{ Items } & \multicolumn{4}{|c|}{ Public Universities } & \multicolumn{4}{|c|}{ Private Universities } \\
\hline & & \multicolumn{2}{|c|}{ Favourable } & \multicolumn{2}{|c|}{ Unfavuorable } & \multicolumn{2}{|c|}{ Favourable } & \multicolumn{2}{|c|}{ Unfavourable } \\
\hline & & $\mathrm{F}$ & $\%$ & $\mathrm{~F}$ & $\%$ & $\mathrm{~F}$ & $\%$ & $\mathrm{~F}$ & $\%$ \\
\hline 1. & Physical facilities & 216 & 49.1 & 224 & 50.9 & 27 & 61.4 & 17 & 38.6 \\
\hline 2. & Information services & 237 & 53.9 & 203 & 46.1 & 28 & 63.6 & 16 & 36.4 \\
\hline 3. & Motivation & 241 & 54.8 & 199 & 45.2 & 34 & 77.3 & 10 & 22.7 \\
\hline 4. & Authority-staff relationship & 255 & 58.0 & 185 & 42.0 & 29 & 65.9 & 15 & 34.1 \\
\hline 5. & Participation in decision making & 247 & 56.1 & 193 & 43.9 & 25 & 56.8 & 19 & 43.2 \\
\hline 6. & Staff development & 268 & 60.9 & 172 & 39.1 & 33 & 75.0 & 11 & 25.0 \\
\hline & Mean & 244 & 55.5 & 196 & 44.5 & 29 & 66.7 & 15 & 33.3 \\
\hline
\end{tabular}

Table 2 compares the work environment of academic staff in public and private universities. According to the table, on the average, $55.5 \%$ of the respondents indicated that the work environment in public universities was favourable while an average of $66.7 \%$ of them indicated that the work environment in private universities was favourable. This means that the work environment of academic staff in private universities was better than that of public universities.

Hypothesis 1: There is no significant difference in the work environment of federal and state universities.

This hypothesis was tested using the responses to items in WEQ. The result was presented in Table 3.

Table 3: t-test Summary of Work Environment of Federal and State Universities

\begin{tabular}{|c|c|c|c|c|c|c|}
\hline Items & $\mathbf{N}$ & $\ddot{\mathbf{x}}$ & SD & DF & t cal & t tab \\
\hline Federal universities & 240 & 138.35 & 16.01 & \multirow[b]{2}{*}{438} & \multirow[b]{2}{*}{23.42} & \multirow[b]{2}{*}{1.96} \\
\hline State universities & 200 & 98.45 & 19.73 & & & \\
\hline
\end{tabular}

$\mathrm{P}<0.05$

Table 3 shows the difference in the work environment of federal and state universities. The results from the analysis show that the value of t-calculated (23.42) is greater than the t-table (1.96); therefore, the null hypothesis is rejected at 0.05 level of significance. That means there is significant difference in the work environment of federal and state universities. The result shows that the mean score of federal university (138.35) is greater than the mean score of state university (98.45). This shows that the work environment is better in federal universities than state universities.

Hypothesis 2: There is no significant difference in the work environment of private and public universities.

This hypothesis was tested using the responses to items in WEQ. The results are presented in Table 4.

Table 4: t-test Summary of Work Environment of Private and Public Universities

\begin{tabular}{|c|c|c|c|c|c|c|}
\hline Items & $\mathbf{N}$ & $\ddot{\mathbf{x}}$ & SD & DF & t cal & t tab \\
\hline Private universities & 44 & 122.07 & 20.81 & \multirow[b]{2}{*}{482} & \multirow[b]{2}{*}{0.45} & \multirow[b]{2}{*}{1.96} \\
\hline Public universities & 440 & 120.21 & 26.68 & & & \\
\hline
\end{tabular}

$\mathrm{P}>0.05$

Table 4 shows the difference in the work environment of private and public universities. The results obtained from the analysis show that the value of t-calculation (0.45) is less than t-table (1.96). Therefore, the null hypothesis is not rejected. That means there is no significant difference in the work environment of private and public universities.

\section{DISCUSSION}

The study revealed that the work environment of academic staff in the federal universities was favourable than that of the state universities. The favourable work environment might be connected with the provision of physical facilities, information services, motivation authority-staff relationship participation in decision-making and 
staff development that were made available in the federal universities than the state universities. This is contrary to some public views that work environment in both federal and state universities were not favourable. The findings of this study are in line with that of Adesina (1983), Ajani (1988) and Adeyemi (2000) that academic staff scrambles for federal universities in preference to state universities because of their belief that most federal universities have conducive environment and they also catered to their staff than those in the state universities.

The results also show that there was significant difference in the work environment of federal and state universities in favour of the federal universities. The reason for this might be disconnected with better funding of the federal universities. The results showed that work environments in public and private universities were favourable, but that of private universities was better than that of public universities. The favourable work environment might be disconnected with the various components of work environment made available in the universities, which include physical facilities, information services, motivation, authority-staff relationship, participation in decision-making and staff development. The findings of the study are in line with that of Winkler \& Round (1996), Tomar (1996), Scheerens \& Bosker (1997) and Seatle (2005), while it contradicts that of Lubienski (2005).

The results also showed that there was no significant difference in the work environment of private and public universities. The findings imply that whether a university is public or private does not make a difference in the work environment. The reason might be due to the fact that government and owners of private universities provide better work environments for their academic staff.

\section{CONCLUSION}

Based on the findings of this study, the following conclusions were made:

- Ownership and type of universities are major variables influencing work environments of universities.

- Ownership of universities made a difference in work environment while the type of universities made no difference in work environments.

\section{RECOMMENDATIONS}

Based on the findings of the study, it was recommended that owners of the universities should provide a favourable environment.

Since work environment significantly differed between federal and state universities in favour of the federal universities, the proprietors of the state universities and stakeholders should make the work environment of the state universities more conducive so that they can compete favourably with their federal counterparts. More attention should be given to the provision of physical facilities, information services, motivation, authority-staff relationship, participation in decision-making process and staff development.

\section{AUTHOR INFORMATION}

Dr. Babatope Bukola Arogundade, is a Lecturer in the Department of Educational Foundations and Management Faculty of Education, Universities of Ado-Ekiti Nigeria. His area of teaching and research is educational administration and school effectiveness. He has presented several papers in many learned conferences of which some have been published. He is a member of the National Association for Educational Administration and Planning [NAEAP]. E-mail: $\underline{\mathrm{dr} \text { arogundade@yahoo.com }}$

\section{REFERENCES}

1. Akangobn, S.D. (1985). The economics of educational planning in Nigeria. New Delhi: Vikas publishing House pvt. Ltd.

2. Arogundade, B.B. (2009). Work environment and job performance of academic staff in South West Nigerian universities, Ado-Ekiti. Unpublished Ph.D Thesis Department of Educational Foundation and Management, Faculty of Education, University of Ado-Ekiti. 
3. Adesina, .S. (1983). Planning and educational development in Nigeria. Lagos: Educational Industries Nigeria Ltd.

4. Ajani, A. (1988). Determination of occupational stress dining Teachers in Nigeria. Educational Studies 15.1:23-31.

5. Adeyemi, J.K (2000). Academic manpower needs of Nigerian Universities. Higher Education Review 32(2):36-44.

6. Ogunsanya, M. (2000). Impact of campus secret cult organization on university administration: A case study of the University of Ibadan, Nigeria. In Lebeau, Y and Ogunsanya, m. [Eds] The Dilemma of PostColonial Universities, Ibadan, Nigeria. IFRA/Africa Book Builders. pp. 75-92.

7. Hartnett, T. (2006). Financing trends and expenditure pattern in Nigerian Federal Universities: An update, Washington, D.C: The World Bank.

8. Alani, R.A (2000). Educational and employment opportunities in Nigeria. In Tt. Ajayi \& R.A Alani (Eds) Contemporary Series In Nigerian Education (pp 145-156) Ijebu-Ode: Triumph Books Publisher.

9. Bruns, B. (2003). Academy Universal Primary Education by 2015: A Chance for every child. World Bank Publication.

10. Lubienski, S.T (2005). A new look at public and private schools Background and mathematics achievement Australia, phi data Kappa international.

11. Winkler, R.W \& Rounds, T (1996), "Municipal and private sector response to decentralization and school choice in Chile" About the ILO Economics of Education Review, 15 (4).

12. Scheereens, J \& Bosker, R (1997). The foundations of education effectiveness. Killington/New York/Tokyo: PERGAMON. Teddie, Cand Reynolds, D. (2000). The International Handbook Of School Effectiveness Research. London Faimer.

13. Seatle, S (2005). "Public and Private Schools" in Teresa Mendez, (2005) "public schools: Do they outperform private ones? "Christian Science Monitor http://www.freerepublic.com

14. Tomar, E. (1996). Public funding and private schooling across countries. Journal of law and Economics, 39 (1). 